\title{
Spiroplasma chrysopicola sp. nov., Spiroplasma gladiatoris sp. nov., Spiroplasma helicoides sp. nov., and Spiroplasma tabanidicola sp. nov., from Tabanid (Diptera: Tabanidae) Flies
}

\author{
ROBERT F. WHITCOMB, ${ }^{1 *}$ FRANK E. FRENCH,${ }^{2}$ JOSEPH G. TULLY, ${ }^{3}$ GAIL E. GASPARICH, ${ }^{4}$ \\ DAVID L. ROSE ${ }^{3}$ PATRICIA CARLE, ${ }^{5}$ JOSEPH M. BOVÉ, ${ }^{5}$ ROBERTA B. HENEGAR, ${ }^{1}$ \\ MEGHNAD KONAI, ${ }^{4}$ KEVIN J. HACKETT, ${ }^{4}$ JEAN R. ADAMS, ${ }^{4}$ \\ TRUMAN B. CLARK ${ }^{4} \dagger$ AND DAVID L. WILLIAMSON ${ }^{6}$
}

Vegetable Laboratory, ${ }^{1}$ and Insect Biocontrol Laboratory, ${ }^{4}$ U. S. Department of Agriculture, Beltsville, Maryland $20705^{1}$; Department of Biology, Georgia Southern University, Statesboro, Georgia 30460²; Mycoplasma Section, Laboratory of Molecular Microbiology, National Institute of Allergy and Infectious Diseases, Frederick Cancer Research Facility, Frederick, Maryland 217023; Laboratoire de Biologie Cellulaire et Moléculaire, Institut Nationale de Recherche Agronomique, 33883 Villenave d'Ornon Cedex, France ; and Department of Anatomical Sciences, State University of New York, Stony Brook, New York $11794^{6}$

\begin{abstract}
Four spiroplasma strains, DF-1 ${ }^{\mathrm{T}}$, TG-1 ${ }^{\mathrm{T}}$, TABS-2 ${ }^{\mathrm{T}}$, and TAUS-1 ${ }^{\mathrm{T}}$, all of which were isolated from deerflies or horseflies (Diptera: Tabanidae), were serologically distinct from previously described spiroplasma species, groups, and subgroups. Strain DF-1 ${ }^{\mathrm{T}}$ originated from a Maryland deerfly (Chrysops sp.); strain TG-1 $^{\mathrm{T}}$ was isolated from a Maryland horsefly (Tabanus gladiator); strain TAUS-1 ${ }^{\mathrm{T}}$ originated from a member of the Tabanus abdominalis-limbatinevris complex of horseflies collected in Maryland; and strain TABS- ${ }^{\mathrm{T}}$ was isolated from a horsefly (Tabanus abactor) collected in Oklahoma. Cells of all of the strains appeared to be helical and motile when they were examined by dark-field microscopy. Cells of strain DF-1 ${ }^{\mathrm{T}}$ growing in M1D medium were short helices with less than six turns; the helical cells of the other strains were long and usually had six or more turns. The short cells of strain DF-1 ${ }^{\mathrm{T}}$ passed through 450 - and $300-\mathrm{nm}$ filter pores with no reduction in titer, but the longer cells of the other strains were partially retained by $450-\mathrm{nm}$-pore-size filters. Electron microscopic examination of all of the strains revealed wall-less cells surrounded only by a single cytoplasmic membrane. All of the strains grew well in SP-4 liquid media and in conventional mycoplasma or M1D media supplemented with horse or fetal bovine serum. Strains TABS-2 ${ }^{\mathrm{T}}$, TAUS-1 ${ }^{\mathrm{T}}$, and DF-1 ${ }^{\mathrm{T}}$ required serum or sterol for growth, but strain TG-1 ${ }^{\mathrm{T}}$ was able to grow in the absence of serum or sterol. The optimum temperatures for growth of the four strains varied from 30 to $32^{\circ} \mathrm{C}$, and growth occurred at 10 to $37^{\circ} \mathrm{C}$. All of the strains catabolized glucose but did not hydrolyze urea. Only strain DF-1 ${ }^{\mathrm{T}}$ hydrolyzed arginine. The guanine-plus-cytosine contents of the DNAs of the strains were: DF-1 ${ }^{\mathrm{T}}, 29 \pm 1 \mathrm{~mol} \%$; TG-1, $26 \pm 1$ mol\%; TABS-2 ${ }^{\mathrm{T}}, 27 \pm 1 \mathrm{~mol} \%$; and TAUS-1 ${ }^{\mathrm{T}}, 26 \pm$ mol\%. The genome sizes of strains DF-1 ${ }^{\mathrm{T}}$ and TAUS- ${ }^{\mathrm{T}}$ were 1,270 and $1,375 \mathrm{kbp}$, respectively. Strain DF-1 (= ATCC 43209), the representative of spiroplasma subgroup VIII-2, is designated the type strain of a new species, Spiroplasma chrysopicola. We also propose that strain TG-1 ${ }^{\mathrm{T}}(=$ ATCC $43525^{\mathrm{T}}$ ), the designated representative of group XXIII, should be placed in a new species, Spiroplasma gladiatoris. In addition, group XXXII spiroplasma strain TABS-2 (= ATCC 51746) is designated the type strain of Spiroplasma helicoides sp. nov., and group XXXIII representative strain TAUS-1 (= ATCC 51747) is designated the type strain of another new species, Spiroplasma tabanidicola.
\end{abstract}

In 1987, an ad hoc committee appointed by the International Committee on Systematic Bacteriology Subcommittee on the Taxonomy of Mollicutes proposed criteria (24) for designating spiroplasma groups. Shortly thereafter, a revised group classification and current list of recognized species of the genus Spiroplasma appeared $(17,19,32)$, which expanded the number of recognized groups to 23 . Two additional species and eight newly proposed (34) group representatives have now increased the number of recognized Spiroplasma groups to 32 (group XVII is vacant) $(18,29,30,34)$. In addition, eight subgroups of group I and three subgroups each of groups VIII and XVI have been recognized $(1,2,7)$.

Since the initial proposal of combined genomic and serological criteria for spiroplasma groups (11), these clusters have

\footnotetext{
* Corresponding author. Mailing address: Vegetable Laboratory, Range 2, HH3, BARCW, Beltsville, MD 20705. Phone: (301) 5048339. Fax: (301) 504-6017.

$\dagger$ Deceased.
}

been regarded as putative species, under the assumption that they represent groups of strains with little or no intergroup DNA-DNA homology. In all of the cases examined, the results of DNA-DNA hybridization studies support this view (32). Therefore, as the number of groups has expanded, groups have continued to represent clusters of organisms that have putative species status but have not been given formal epithets. Under certain circumstances, subgroups can be elevated to the species level (9). In this paper, we report the results of characterization studies that resulted in species names being assigned to three group representatives and one subgroup representative. We propose that the group XXIII spiroplasmas should be placed in a new species, Spiroplasma gladiatoris, whose type strain is strain TG-1 (= ATCC 43525). In addition, group XXXIII spiroplasmas are named Spiroplasma tabanidicola sp. nov., with type strain TAUS-1 (= ATCC 51747), and group XXXII spiroplasmas are named Spiroplasma helicoides sp. nov., with type strain TABS-2 (= ATCC 51746). We also designate subgroup VIII-2 Spiroplasma chrysopicola sp. nov.; the type strain of this species is DF-1 (= ATCC 43209). 


\section{MATERIALS AND METHODS}

Many of the techniques used in this study are standard techniques used for spiroplasma characterization and have been described previously $(13,21,22)$ Departures from these techniques are described below.

Spiroplasma strains. All of the strains were isolated $(14,21,22)$ from the guts of tabanid flies. Strain DF- $1^{\mathrm{T}}$ was isolated by T. B. Clark from a female deerfly (Chrysops sp.) collected at the Patuxent Wildlife Research Center, Laurel, Md (Prince George's County), on 3 July 1983 by J. E. Lowry. Strain TG-1 ${ }^{\text {T }}$ was isolated from a horsefly (Tabanus gladiator) collected at Bucktown, Md., on 16 June 1985. Strain TAUS-1 ${ }^{\mathrm{T}}$ was isolated by F. R. Green from the blood of a female member of the Tabanus abdominalis-limbatinevris complex that he had collected at the Beltsville Agricultural Research Center, Beltsville, Md. (Prince George's County), on 31 July 1986 . Strain TABS-2 ${ }^{\mathrm{T}}$ was isolated from a horsefly (Tabanus abactor) collected near Ardmore, Okla., (Carter County), on $20 \mathrm{Sep}-$ tember 1987. Some of the genomic $(4,19)$ and serological $(19,28)$ features of the organisms have been reported previously. All of the strains were purified by conventional filtration-cloning techniques. Representative strains of all previously recognized groups and subgroups $(18,19,29)$, including the type strains of previously recognized species $(18,34)$, were employed in various parts of this study.

Culture medium and cultivation techniques. Strain DF- $1^{\mathrm{T}}$ was grown in primary culture in SM-1 liquid medium $(23)$ at $30^{\circ} \mathrm{C}$. All other strains were isolated in M1D medium containing $500 \mathrm{U}$ of penicillin per $\mathrm{ml}(23)$. In all cases, after several broth passages, the isolates were lyophilized and revived later for cloning Cultures of all strains were incubated routinely at $30^{\circ} \mathrm{C}$. Following filtrationcloning, triply cloned strains were selected and used in characterization studies. Other medium formulations used included SP-4 medium and serum fraction broth supplemented with $1 \%$ bovine serum fraction (23). Solid media were prepared by adding Noble agar (Difco Laboratories, Detroit, Mich.) to a final concentration of 2.25 or $3.0 \%$. Agar cultures were incubated at $30^{\circ} \mathrm{C}$ either aerobically (with $5 \%$ carbon dioxide; GasPak system [BBL Microbiology Systems, Cockeysville, Md.]) or anaerobically (Hydrogen GasPak system). Temperature requirements for growth were assessed as described previously (12).

Morphological studies. Cells of all strains were grown in broth cultures to the logarithmic phase and were examined at a magnification of $\times 1,250$ by dark-field microscopy. For electron microscopic examination, the strains were grown in approximately $2 \mathrm{ml}$ of broth and pelleted by centrifugation at $4^{\circ} \mathrm{C}$. The pelleted cells were fixed for $2 \mathrm{~h}$ in $3 \%$ glutaraldehyde, postfixed in $1 \%$ osmium tetroxide for $1 \mathrm{~h}$, dehydrated in acetone, embedded in Epon, sectioned, and stained with $1 \%$ aqueous uranyl acetate and Reynold's lead citrate.

Sterol requirement. Sterol requirements for growth were determined by a modified test in which sustained growth was measured through 23 serial 10-fold dilutions in various media with or without animal serum (16). In addition, cholesterol requirements were also studied with a technique modified from the standard broth method. Spiroplasma strains were adapted to grow well in $1 \%$ bovine serum fraction medium; $1 \%$ inocula from this medium were added to serum-free media containing $1,2,5,10$, and $20 \mu \mathrm{g}$ of cholesterol per ml. The response to cholesterol was measured by microscopically counting spiroplasma cells and by titrating color-changing units per milliliter (15)

Tests for biological and biochemical properties. The procedures used to determine glucose fermentation, arginine and urea hydrolysis, and the ability of strains to pass through membrane filters with various pore sizes have been described previously (11)

Serological tests. Antisera to all strains were raised in rabbits as described previously $(31,33)$. Hyperimmune antisera to all previously established Spiroplasma species, groups, putative groups, and subgroups $(18,34)$ were obtained from reference collections at the Beltsville Agricultural Research Center and the National Institute of Allergy and Infectious Diseases laboratory in Frederick, Md. The strains and their antisera were tested reciprocally by performing metabolism inhibition and deformation tests by using previously described techniques $(31,33)$

Genomic analysis. The techniques used to extract and purify mollicute chromosomal DNA, to determine guanine-plus-cytosine contents of purified DNAs (3), and to determine genome sizes by pulsed-field gel electrophoresis have been described previously (4).

\section{RESULTS AND DISCUSSION}

Cultural and morphological properties. All of the strains grew well in M1D and SP-4 media. The strains also grew in conventional mycoplasma media containing horse serum (Edward formulation) and in $1 \%$ bovine serum fraction medium. Strain TG $-1^{\mathrm{T}}$ adapted readily to the latter medium, but the other strains required 5 to 20 passages in mixtures of serum fraction medium and M1D medium before they adapted. All strains were resistant to $500 \mathrm{U}$ of penicillin per $\mathrm{ml}$. The temperature growth requirements have been described previously (12). Strain DF- $1^{\mathrm{T}}$ grew at temperatures between 10 and $32^{\circ} \mathrm{C}$, and the optimum temperature was $30^{\circ} \mathrm{C}$; the doubling time at the optimum temperature was $6.4 \mathrm{~h}$, and the doubling times at $10,15,20,25,30$, and $32^{\circ} \mathrm{C}$ were $105,52.7,23.4,8.5,6.4$, and $8.2 \mathrm{~h}$, respectively. Strain TG-1 ${ }^{\mathrm{T}}$ grew at temperatures between 15 and $37^{\circ} \mathrm{C}$, and the optimum temperature was 30 to $32^{\circ} \mathrm{C}$; the doubling time at the optimum temperature was $4.1 \mathrm{~h}$, and the doubling times at $15,20,25,30,32$, and $37^{\circ} \mathrm{C}$ were $43.3,11.1$, $5.8,4.1,4.1$, and $10.9 \mathrm{~h}$, respectively. Strain TABS- $2^{\mathrm{T}}$ grew at temperatures between 20 and $37^{\circ} \mathrm{C}$, and the optimum temperature was $32^{\circ} \mathrm{C}$; the doubling time at the optimum temperature was $3.0 \mathrm{~h}$, and the doubling times at $20,25,30,32$, and $37^{\circ} \mathrm{C}$ were $13.9,6.0,3.1,3.0$, and $15.5 \mathrm{~h}$, respectively. Strain TAUS $-1^{\mathrm{T}}$ grew at temperatures between 10 and $37^{\circ} \mathrm{C}$, and the optimum temperature was $30^{\circ} \mathrm{C}$; the doubling time at the optimum temperature was $3.7 \mathrm{~h}$, and the doubling times at 15, 20, $25,30,32$, and $37^{\circ} \mathrm{C}$ were $64.3,14.4,14.3,3.7,5.2$, and $10.6 \mathrm{~h}$, respectively. No strain grew during 3 weeks of incubation in broth media at 5 or $43^{\circ} \mathrm{C}$.

The colonial morphologies of the spiroplasma strains on "hard" agar (media containing 2.25 or $3.0 \%$ Noble agar) are shown in Fig. 1. Strain DF-1 ${ }^{\mathrm{T}}$ growing aerobically on solid SP-4 medium containing $2.25 \%$ Noble agar formed colonies that had dense centers, smooth edges, and no satellites (Fig. 1A). Colonies of strain TG- $1^{\mathrm{T}}$ on SP-4 medium containing $3 \%$ Noble agar were granular with dense centers and had no satellites (Fig. 1A). Colonies of strain TABS- $2^{\mathrm{T}}$ growing on SP-4 medium containing $3 \%$ Noble agar were uneven and granular and had dense centers, irregular edges, and no satellites (Fig. 1C). The colonies formed by strain TAUS- $1^{\mathrm{T}}$ growing on SP-4 medium containing $2.25 \%$ Noble agar had smooth edges, were perfectly umbonate, and did not have satellites (Fig. 1D).

Morphological studies. Logarithmic-phase cultures of strain DF- $1^{\mathrm{T}}$ in M1D medium that were examined by dark-field microscopy contained numerous short motile filaments with less than six turns. As previously reported (19), electron microscopy revealed that cells of this organism were filamentous and had no evidence of a cell wall; representative cells were surrounded by a single cytoplasmic membrane. The cells of strains TG $-1^{\mathrm{T}}$, TAUS- $1^{\mathrm{T}}$, and TABS $-2^{\mathrm{T}}$ were long and had more than six turns. These helical cells were surrounded by typical cytoplasmic membranes, and there was no evidence of a cell wall (Fig. 2).

Sterol requirement. In the sustained growth test performed to determine sterol requirements, strains $\mathrm{DF}-1^{\mathbf{T}}$, TABS- ${ }^{\mathrm{T}}$, and TAUS $-1^{\mathrm{T}}$ all grew well in serum-containing media through 23 serial 10 -fold dilutions, but were unable to grow beyond 2 to 5 serial 10-fold dilutions in serum-free medium, whether or not it was supplemented with $0.04 \%$ polyoxyethylene sorbitan (Tween 80 ). On the other hand, strain TG-1 ${ }^{\mathrm{T}}$ did not have a sterol requirement since it grew through more than 3010 -fold serial dilutions in the serum-free broth formulation. This strain, however, did not grow in serum-free medium supplemented with polyoxyethylene sorbitan. In an initial report describing this sterol test method (16), Rose et al. suggested that strain TG- $1^{\mathrm{T}}$ required sterol. However, in our study, the morphology of this strain was monitored by dark-field microscopy, and the organism was subcultured at appropriate intervals in fresh serum-free medium, which provided conditions for prolonged growth of the organism in the absence of serum. The responses of strains TG- $1^{\mathrm{T}}$, TABS- $2^{\mathrm{T}}$, and TAUS $-1^{\mathrm{T}}$ to additions of cholesterol to the base medium in one series of experiments are shown in Table 1. Limited growth occurred in base broth alone that was inoculated with a $1: 100$ or $1: 1,000$ inoculum from serum fraction medium. Growth occurred in the presence of serum fraction in base media inoculated with $10 \%$ inocula, which permitted carryover of serum fraction from the 

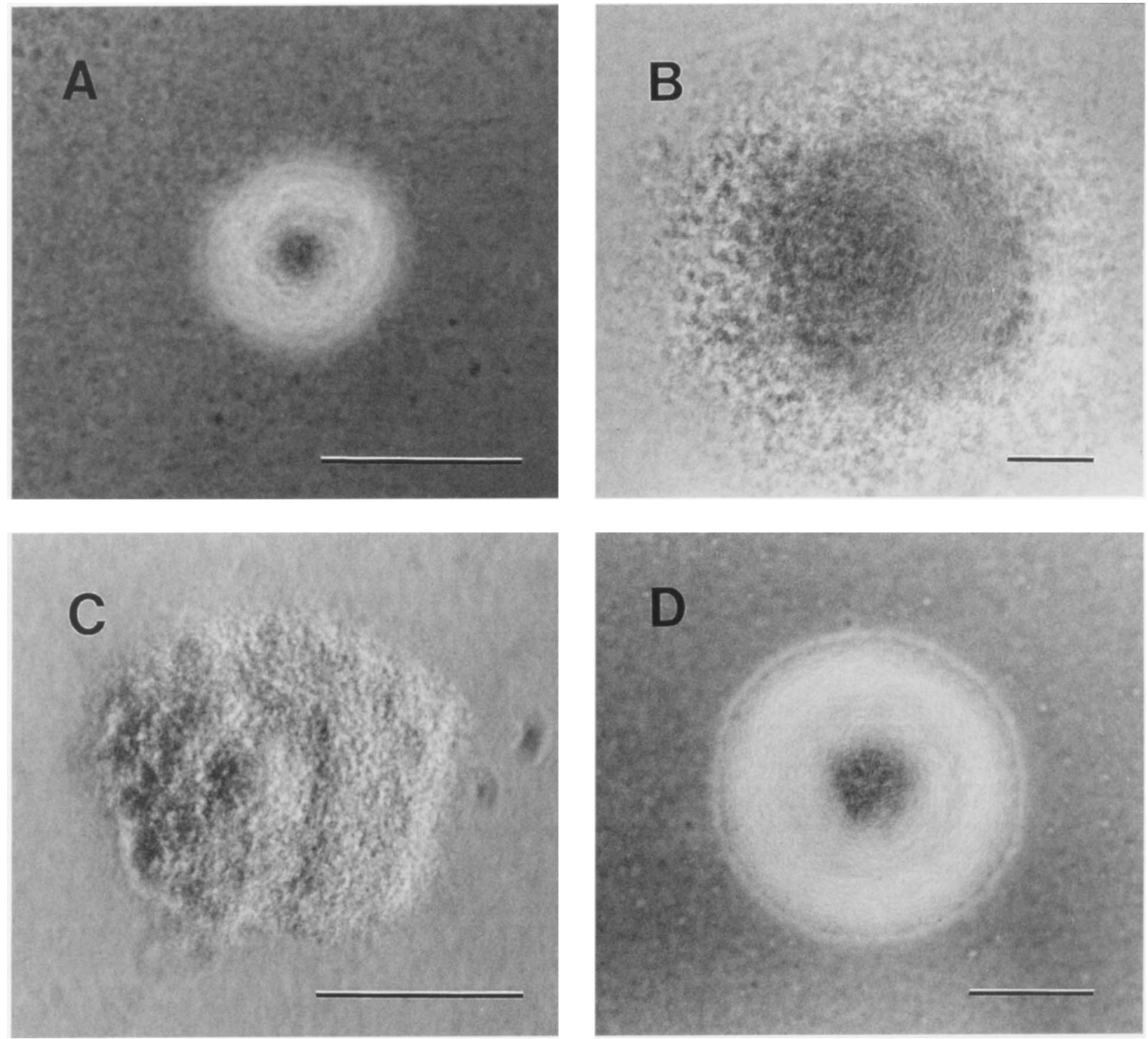

FIG. 1. Colonies of four tabanid-derived spiroplasmas. (A) Strain DF-1 ${ }^{\mathrm{T}}$, passage 3, on SP-4 medium with 2.25\% Noble agar. The organism was grown for 6 days aerobically at $30^{\circ} \mathrm{C}$. (B) Strain TG-1 $1^{\mathrm{T}}$, passage 6 , on SP-4 medium with $3 \%$ Noble agar. The organism was grown for 9 days anaerobically at $30^{\circ} \mathrm{C}$. (C) Strain TABS $-2^{\mathrm{T}}$, passage 41 , on SP-4 medium with $3 \%$ Noble agar. The organism was grown for 8 days anaerobically at $30^{\circ} \mathrm{C}$. (D) Strain TAUS- $1^{\mathrm{T}}$, passage 23 , on SP-4 medium with $2.25 \%$ Noble agar. The organism was grown for 9 days aerobically at $30^{\circ} \mathrm{C}$. Bars $=50 \mu \mathrm{m}$.

inoculating media. Growth also occurred in media that were supplemented with 1 to $20 \mu \mathrm{g}$ of cholesterol per $\mathrm{ml}$; lower concentrations did not stimulate growth as much as higher concentrations.

Biochemical and biological properties. All of the strains produced acid from glucose, but none hydrolyzed urea. Strain $\mathrm{DF}-1^{\mathrm{T}}$, but not the other strains, hydrolyzed arginine. Passage of broth cultures of strain DF- $1^{\mathrm{T}}$ through membrane filters with 450 - or 300 -nm pores failed to reduce the viable cell titer; the organism did not pass through $100-\mathrm{nm}$ filter pores. Passage of broth cultures of strain TG- $1^{\mathrm{T}}$ through membrane filters with $450-, 300-$, and 220 -nm pores reduced the viable cell titers by 1,2 , and $3 \log _{10}$ units, respectively. Passage of broth cultures of strain TABS-2 ${ }^{\mathrm{T}}$ through membrane filters with 450-, 300-, and 220 -nm pores reduced the viable cell titers by 2,0 , and 1 $\log _{10}$ units, respectively. Passage of broth cultures of strain TAUS $-1^{\mathrm{T}}$ through membrane filters with $450-\mathrm{nm}$ pores re- duced the titer 10-fold; passage through 220-nm-pore-size filters reduced the titer 100 -fold. All strains failed to pass through filters with $100-\mathrm{nm}$ pores.

Serological tests. The results of metabolism inhibition and spiroplasma deformation tests performed with antisera directed against previously described spiroplasma species, groups, subgroups, and putative species indicated that strains $\mathrm{TG}-1^{\mathbf{T}}$, TAUS- ${ }^{\mathrm{T}}$, and TABS $-2^{\mathrm{T}}$ are serologically unrelated to other Spiroplasma representatives or type strains (Table 2) $(18,34)$. Low-level (1:40) reciprocal deformation cross-reactions were observed with strain TG- $1^{\mathrm{T}}$ and strain I-25 (group XV). Other reciprocal deformation and metabolism inhibition cross-reactions (Table 2) were observed only with strain $D F-1^{T}$ and representatives of other group VIII subgroups, including strain EA-1 ${ }^{\mathbf{T}}$ (Spiroplasma syrphidicola; subgroup VIII-1) and strain TAAS-1 (subgroup VIII-3) $(7,25,34)$. We have recently reported (25) that strain B1357, a representative of a large as- 

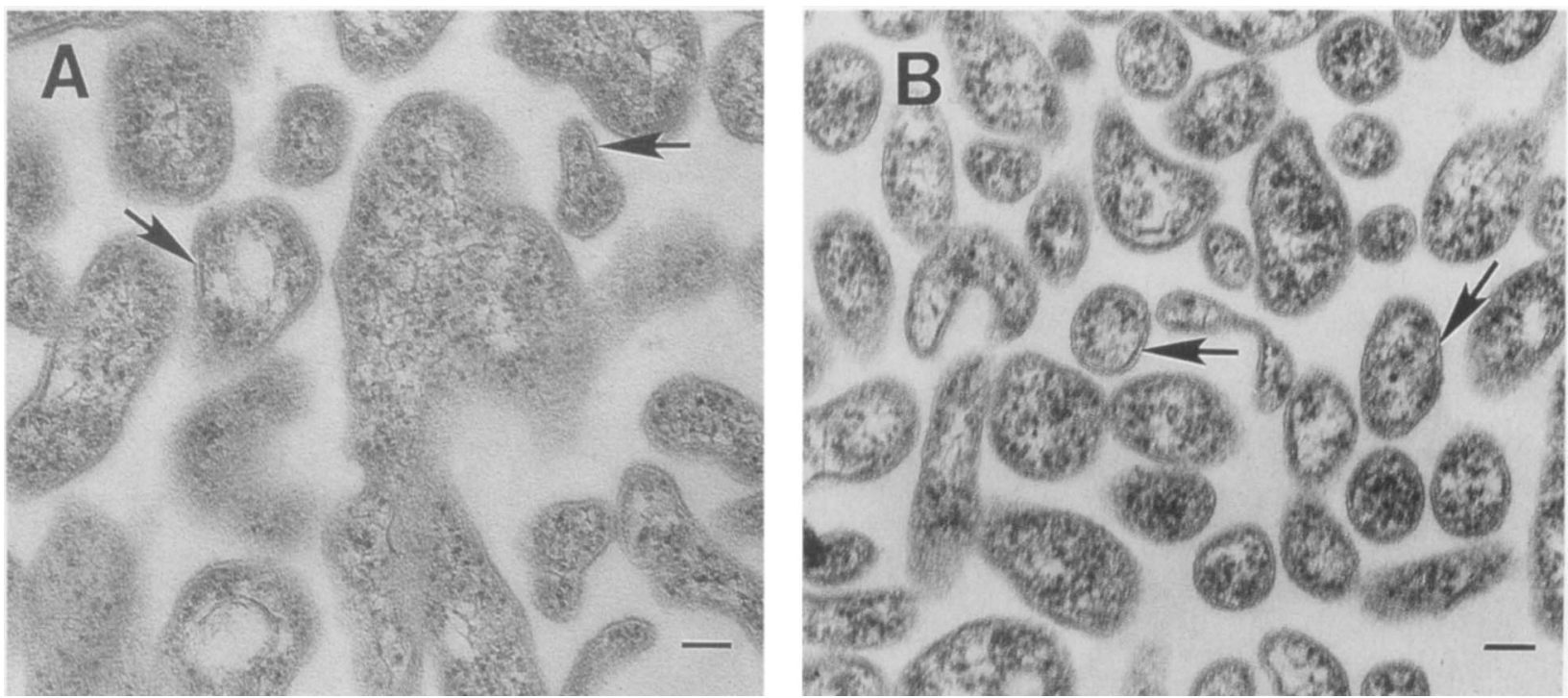

FIG. 2. Electron micrograph of sectioned and stained cells of strain TABS- $2^{\mathrm{T}}(\mathrm{A})$ and strain TAUS-1 ${ }^{\mathrm{T}}(\mathrm{B})$. Sections were stained with $2 \%$ aqueous uranyl acetate and Reynold's lead citrate. The arrows indicate the unit membrane. Bar $=100 \mathrm{~nm}$.

semblage of isolates obtained from Tabanus lineola, is partially related to all three group VIII subgroups, but cannot be classified in any of them.

Justification for elevation of subgroup VIII-2. There are now three clusters of spiroplasma subgroups. Group I is subdivided into eight subgroups $(2,32,34)$, and group XVI is subdivided into three subgroups (1). In 1993, Gasparich et al. (7) subdivided group VIII into three subgroups. Initially, strain DF $-1^{\mathrm{T}}$ fit the criteria used to classify spiroplasma strains into groups (24) and was classified as a member of group XVII (17). However, a large array of spiroplasma isolates obtained from dipterous insects, including horseflies and deerflies (Diptera: Tabanidae), have been found to cross-react significantly with both group VIII strain EA-1 ${ }^{\mathrm{T}}$ (27) and strain DF-1 ${ }^{\mathrm{T}}$. One of the group VIII strains, TAAS-1, which was isolated from a horsefly, was studied in detail (5). Strains EA- $1^{\mathrm{T}}, \mathrm{DF}-1^{\mathrm{T}}$, and TAAS- 1 were found to be serologically interreactive $(7,29)$. Strains EA- $1^{\mathrm{T}}, \mathrm{DF}-1^{\mathrm{T}}$, and TAAS- 1 had similar $\mathrm{G}+\mathrm{C}$ contents $(30 \pm 1 \mathrm{~mol} \%)$. Strains DF-1 ${ }^{\mathrm{T}}$ and EA- $1^{\mathrm{T}}$ exhibited levels of DNA-DNA homology of 33 to $48 \%$, while strain TAAS- 1 exhibited levels of homology of 42 and $67 \%$ with strains DF-1 ${ }^{\mathrm{T}}$ and $\mathrm{EA}-1^{\mathrm{T}}$, respectively. These data confirm that the levels of genomic relatedness of strain DF- $1^{\mathrm{T}}$ to other group VIII strains are low enough to justify designation of this strain as a member of a new species, in accordance with current concepts of microbial species identification (10). Strain DF- $1^{\mathrm{T}}$ appears to be confined to deerflies; thus, it exhibits the ecological specialization expected of a subgroup elevated to species status (8).

Genome sizes and DNA base compositions. The genome size of strain DF- $1^{\mathrm{T}}$ has been reported to be $1,270 \mathrm{kbp}(4)$. The genome size of strain TAUS- $1^{\mathrm{T}}$ was determined to be 1,375 kbp by pulsed-field gel electrophoresis (4). The genome sizes of strains TG- $1^{\mathrm{T}}$ and TABS- $2^{\mathrm{T}}$ have not been determined yet. The base composition (guanine-plus-cytosine content) of the DNA of strain DF- $1^{\mathrm{T}}$, as determined $(7,19)$ by the buoyant density, melting temperature, and high-performance liquid chromatography methods, was $29 \pm 1$ mol\%. The base compositions of strains TG $-1^{\mathrm{T}}$, TAUS $-1^{\mathrm{T}}$, and TABS- $2^{\mathrm{T}}$, as determined by the buoyant density method, were $26 \pm 1,27 \pm 1$, and $26 \pm 1 \mathrm{~mol} \%$, respectively.
Habitats. All of the strains described here were isolated from the abdominal viscera of adult female tabanids. The relative specificity of carriage of these and related strains can be assessed by examining the results of comparative studies in which hundreds of spiroplasma cultures were obtained (6) from tabanids collected on coastal plains from Florida to Nova

TABLE 1. Growth responses of strains TG- ${ }^{\mathrm{T}}$, TABS- $2^{\mathrm{T}}$, and TAUS- $1^{\mathrm{T}}$ to cholesterol ${ }^{a}$

\begin{tabular}{|c|c|c|c|c|}
\hline \multirow[t]{2}{*}{ Strain } & \multirow{2}{*}{$\begin{array}{l}\text { Supplement added to } \\
\text { serum-free base } \\
\text { medium }\end{array}$} & \multirow{2}{*}{$\begin{array}{l}\text { Cholesterol } \\
\text { concn } \\
(\mu \mathrm{g} / \mathrm{ml})\end{array}$} & \multicolumn{2}{|c|}{$\begin{array}{c}\text { Growth response } \\
\text { (color-changing } \\
\text { units } / \mathrm{ml} \text { ) on: }\end{array}$} \\
\hline & & & Day 2 & Day 3 \\
\hline TG $-1^{\mathrm{T}}$ & $\begin{array}{l}\text { Serum fraction } \\
\text { None } \\
\text { Cholesterol }\end{array}$ & $\begin{array}{r}0 \\
0 \\
1 \\
2 \\
5 \\
10 \\
20\end{array}$ & $\begin{array}{l}8 \\
6 \\
6 \\
6 \\
6 \\
6 \\
6\end{array}$ & $\begin{array}{l}7 \\
5 \\
7 \\
6 \\
7 \\
8 \\
8\end{array}$ \\
\hline TABS $-2^{T}$ & $\begin{array}{l}\text { Serum fraction } \\
\text { None } \\
\text { Cholesterol }\end{array}$ & $\begin{array}{r}0 \\
0 \\
1 \\
2 \\
5 \\
10 \\
20\end{array}$ & $\begin{array}{l}9 \\
4 \\
6 \\
6 \\
6 \\
8 \\
9\end{array}$ & $\begin{array}{l}4 \\
4 \\
4 \\
4 \\
6 \\
6 \\
7\end{array}$ \\
\hline TAUS-1 $^{\mathrm{T}}$ & $\begin{array}{l}\text { Serum fraction } \\
\text { None } \\
\text { Cholesterol }\end{array}$ & $\begin{array}{r}0 \\
0 \\
1 \\
2 \\
5 \\
10 \\
20\end{array}$ & $\begin{array}{l}8 \\
4 \\
6 \\
6 \\
6 \\
6 \\
8\end{array}$ & $\begin{array}{l}3 \\
3 \\
5 \\
5 \\
5 \\
5 \\
5\end{array}$ \\
\hline
\end{tabular}

${ }^{a}$ All media were inoculated with $10^{6}$ color-changing units of a logarithmicphase culture of the strain in base medium supplemented with serum fraction. The growth responses were determined 2 and 3 days after inoculation. Phenol red $\mathrm{pH}$ indicator indicated that there was significant acid production in cultures containing $10^{8}$ or $10^{9}$ color-changing units $/ \mathrm{ml}$. 
TABLE 2. Serological reactivities of the four new spiroplasma species ${ }^{a}$

\begin{tabular}{|c|c|c|c|c|c|c|}
\hline \multirow{3}{*}{ Strain } & \multirow{2}{*}{\multicolumn{2}{|c|}{ Challenge organism }} & \multicolumn{4}{|c|}{ Titer in: } \\
\hline & & & \multicolumn{2}{|c|}{ Deformation test } & \multicolumn{2}{|c|}{ Metabolism inhibition test } \\
\hline & Group & Strain & Antigen $^{b}$ & Antiserum $^{c}$ & Antigen $^{d}$ & Antiserum \\
\hline \multirow[t]{11}{*}{ DF-1 ${ }^{\mathrm{T}}$ (group VIII-2) } & I-1 & $\mathrm{R} 8 \mathrm{~A} 2^{\mathrm{T}}$ & $\mathrm{n}^{f}$ & $\mathrm{n}$ & $\mathrm{n}$ & 54 \\
\hline & $\mathrm{I}-2$ & $\mathrm{E} 275^{\mathrm{T}}$ & $\mathrm{n}$ & $\mathrm{n}$ & $\mathrm{n}$ & 54 \\
\hline & II & DW-1 & $\mathrm{n}$ & $\mathrm{n}$ & $\mathrm{n}$ & 1,458 \\
\hline & VIII-1 & $\mathrm{EA}-1^{\mathrm{T}}$ & $\mathrm{n}$ & 80 & 54 & 486 \\
\hline & VIII-2 & $\mathrm{DF}-1^{\mathrm{T}}$ & $10,240^{g}$ & 10,240 & 117,000 & 117,000 \\
\hline & VIII-3 & TAAS-1 & 160 & 80 & 486 & 54 \\
\hline & XVI-3 & Ar- 1357 & $\mathrm{n}$ & $\mathrm{n}$ & 54 & $\mathrm{n}$ \\
\hline & XIX & PUP-1 $^{\mathbf{T}}$ & $\mathrm{n}$ & 40 & $\mathrm{n}$ & $\mathrm{n}$ \\
\hline & $X X$ & $\mathrm{LD}-1^{\mathrm{T}}$ & $\mathrm{n}$ & $\mathrm{n}$ & $\mathrm{n}$ & 54 \\
\hline & XXVI & PLHS-1 & $\mathrm{n}$ & $\mathrm{n}$ & $\mathrm{n}$ & 162 \\
\hline & XXXIII & TAUS- $1^{\mathrm{T}}$ & $\mathrm{n}$ & $\mathrm{n}$ & 54 & $\mathrm{n}$ \\
\hline \multirow[t]{8}{*}{ TG-1 $1^{\mathrm{T}}$ (group XXIII) } & II & DW-1 & $\mathrm{n}$ & $\mathrm{n}$ & $\mathrm{n}$ & 54 \\
\hline & XIV & $\mathrm{EC}-1^{\mathrm{T}}$ & $\mathrm{n}$ & 40 & $\mathrm{n}$ & $\mathrm{n}$ \\
\hline & XV & $\mathrm{I}-25$ & 40 & $\mathrm{n}$ & $\mathrm{n}$ & $\mathrm{n}$ \\
\hline & XIX & PUP-1 $^{\mathrm{T}}$ & $\mathrm{n}$ & 40 & $\mathrm{n}$ & $\mathrm{n}$ \\
\hline & $X X$ & $\mathrm{LD}^{-1}{ }^{\mathrm{T}}$ & $\mathrm{n}$ & $\mathrm{n}$ & $\mathrm{n}$ & 486 \\
\hline & XXII & $\mathrm{CT}-1^{\mathrm{T}}$ & 40 & $\mathrm{n}$ & $\mathrm{n}$ & $\mathrm{n}$ \\
\hline & XXIII & TG-1 ${ }^{\mathrm{T}}$ & $20,480^{g}$ & 20,480 & 117,000 & 117,000 \\
\hline & XXVI & PLHS-1 & $\mathrm{n}$ & 160 & $\mathrm{n}$ & 54 \\
\hline \multirow[t]{9}{*}{ TABS-2 ${ }^{\mathrm{T}}$ (group XXXII) } & I-2 & $\mathrm{E} 275^{\mathrm{T}}$ & $\mathrm{n}$ & 40 & $\mathrm{n}$ & $\mathrm{n}$ \\
\hline & $\mathrm{I}-8$ & $\mathrm{P} 40^{\mathrm{T}}$ & $\mathrm{n}$ & $\mathrm{n}$ & $\mathrm{n}$ & 162 \\
\hline & XI & $\mathrm{MQ}-4^{\mathrm{T}}$ & $\mathrm{n}$ & $\mathrm{n}$ & $\mathrm{n}$ & 54 \\
\hline & XIX & PUP-1 ${ }^{\mathrm{T}}$ & $\mathrm{n}$ & 40 & $\mathrm{n}$ & 162 \\
\hline & $X X$ & LD-1 ${ }^{\mathrm{T}}$ & $\mathrm{n}$ & $\mathrm{n}$ & $\mathrm{n}$ & 54 \\
\hline & XXVI & PLHS-1 & $\mathrm{n}$ & $\mathrm{n}$ & $\mathrm{n}$ & 54 \\
\hline & XXVIII & PALS-1 & $\mathrm{n}$ & $\mathrm{n}$ & $\mathrm{n}$ & 54 \\
\hline & XXXI & HYOS-1 & $\mathrm{n}$ & 40 & $\mathrm{n}$ & $\mathrm{n}$ \\
\hline & XXXII & TABS- $2^{\mathrm{T}}$ & 640 & 640 & 39,000 & 39,000 \\
\hline \multirow[t]{8}{*}{ TAUS-1 ${ }^{\mathrm{T}}$ (group XXXIII) } & $\mathrm{I}-8$ & $\mathrm{P} 40$ & $\mathrm{n}$ & $\mathrm{n}$ & $\mathrm{n}$ & 54 \\
\hline & VIII-2 & DF-1 & $\mathrm{n}$ & $\mathrm{n}$ & $\mathrm{n}$ & 54 \\
\hline & XIX & PUP-1 ${ }^{\mathrm{T}}$ & $\mathrm{n}$ & $\mathrm{n}$ & $\mathrm{n}$ & 486 \\
\hline & XX & LD- $1^{\mathrm{T}}$ & $\mathrm{n}$ & $\mathrm{n}$ & $\mathrm{n}$ & 162 \\
\hline & XXI & W115 & $\mathrm{n}$ & $\mathrm{n}$ & $\mathrm{n}$ & 54 \\
\hline & XXVI & PLHS-1 & $\mathrm{n}$ & $\mathrm{n}$ & $\mathrm{n}$ & 162 \\
\hline & XXVIII & PALS-1 & $\mathrm{n}$ & $\mathrm{n}$ & $\mathrm{n}$ & 54 \\
\hline & XXXIII & TAUS $^{-1}{ }^{\mathrm{T}}$ & 5,120 & 5,120 & 39,000 & 39,000 \\
\hline
\end{tabular}

${ }^{a}$ Antigens and antisera of the strains were tested in all combinations against all known and putative groups and subgroups. All cross-reactions except those shown were negative.

${ }^{b}$ Reciprocal of the endpoint in a deformation test in which the antigen was tested against a heterologous antiserum.

${ }^{c}$ Reciprocal of the endpoint in a deformation test in which the antiserum was tested against a heterologous antigen.

${ }^{d}$ Reciprocal of the endpoint in a metabolism inhibition test in which the antigen was tested against a heterologous antiserum.

${ }^{e}$ Reciprocal of the endpoint in a metabolism inhibition test in which the antiserum was tested against a heterologous antigen.

${ }^{\prime} \mathrm{n}$, negative.

${ }^{g}$ Homologous titer of the strain in the test system. The reaction, obtained only once, is listed in each column for completeness.

Scotia and in the Rocky Mountains from Montana to New Mexico. Other collection sites were located in Vermont and Texas. The most extensive survey was made during 1987 to 1995 at four sites in Bulloch County, Georgia. We used oneway serological deformation tests (28) to identify more than 400 cultures isolated from tabanids in these comparative studies.

Strain DF-1 ${ }^{\mathrm{T}}$ was isolated from a deerfly (Chrysops $\mathrm{sp}$.) from Prince George's County, Maryland. Thirteen related strains were isolated from six Chrysops spp. from Bulloch County, Georgia, and Yellowstone National Park, Wyoming. Most group VIII spiroplasmas (7) react to some degree with antiserum directed against strain DF-1 ${ }^{\mathrm{T}}$. However, no isolates identified as $S$. chrysopicola were obtained from many tabanids belonging to other horsefly genera that were collected with the
Chrysops spp. There is therefore an apparent natural exclusive relationship between strains referable to $S$. chrysopicola and deerflies (Chrysops spp.). Strains TG $-1^{\mathrm{T}}$ and TAUS-1 ${ }^{\mathrm{T}}$ were isolated from tabanid flies from Maryland, and strain TABS $-2^{\mathrm{T}}$ was isolated from a tabanid fly from Texas. Isolates closely related to these strains have been isolated from insects collected in Georgia, Florida, and North Carolina. These three tabanid spiroplasmas therefore appear to have southern and southeastern United States distributions, since they have not appeared in collections from Wyoming, Vermont, Connecticut, and Nova Scotia, Canada.

Isolates related to strain TG-1 $1^{\mathrm{T}}$ were commonly carried by horseflies in the southeastern United States (26). These organisms were recovered from individual females of Chlorotabanus crepuscularis, from one Chrysops vittatus specimen, and from 
more than 100 individuals belonging to 11 Tabanus species. The largest number of cultures referable to $S$. gladiatoris came from Tabanus americanus, $T$. gladiator, and Tabanus lineola. Most of these isolates came from Bulloch County, Georgia. $S$. gladiatoris often occurs in mixed infections with other spiroplasma species.

Isolates related to strain TAUS $-1^{\mathrm{T}}$ were recovered only from members of the horsefly subfamily Tabaninae. These isolates were identified by deformation tests in one culture from $\mathrm{Leu}$ cotabanus annulatus and in 10 cultures from Hybomitra difficilus. Isolates related to strain TAUS $-1^{\mathrm{T}}$ were frequently recovered from $T$. gladiator and $T$. lineola. Cultures of $S$. tabanidicola from $T$. lineola generally gave deformation endpoints of 1:640 or $1: 1,280$, compared to a homologous titer of 5,120 . This spiroplasma species was also isolated from Tabanus atratus, Tabanus imitans, and Tabanus subsimilus. The majority of the TAUS $-1^{\mathrm{T}}$ isolations were from insects from Bulloch County, Georgia, but there were also isolations from tabanids captured in Johnston County, North Carolina, Carteret County, North Carolina, and Alachua County, Florida.

Strain TABS- $2^{\mathrm{T}}$ was isolated from $T$. abactor from Carter County, Oklahoma. Related isolates were obtained from $H$. difficilus; these strains represented about $40 \%$ of the isolations from this species, whose flight activity is restricted to April in Bulloch County, Georgia. Strains related to TABS- $2^{\mathrm{T}}$ were also isolated from three horseflies (T. americanus, $T$. gladiator, and $T$. lineola) whose flight activities range from late spring through early fall. However, the isolates related to strain TABS $-2^{\mathrm{T}}$ comprised only a small fraction of the isolations from these Tabanus spp. In all cases, the significance of antigenic variation among the type strains and related isolates of tabanid spiroplasmas has yet to be determined.

The properties described here for strains $\mathrm{DF}-1^{\mathrm{T}}, \mathrm{TG}-1^{\mathrm{T}}$, TABS $-2^{\mathrm{T}}$, and TAUS $-1^{\mathrm{T}}$ fulfill proposed criteria (8) for descriptions of species of the class Mollicutes, including the absence of a cell wall, filterability, and penicillin resistance. The helicity and motility of these strains and the inability of the strains to utilize urea place them (20) in the order Entomoplasmatales and the family Spiroplasmataceae. Finally, the results of serological comparisons of these strains, other Spiroplasma species, and group representatives confirm that they are members of separate Spiroplasma species. We therefore propose the designations below for these organisms.

Description of Spiroplasma chrysopicola sp. nov. Spiroplasma chrysopicola (chry.so.pi.'co.la. Gr. n. Chrysops, a genus of deerflies in the Tabanidae L. v. colo, to inhabit; N. L. adj. chrysopicola, inhabiting Chrysops spp.).

Cells are filamentous, helical, and motile and lack a cell wall. Colonies on solid medium containing $2.25 \%$ Noble agar have dense centers and smooth edges (a "fried-egg" appearance) and do not have satellites.

Chemoorganotroph. Acid is produced from glucose. Hydrolyzes arginine but not urea.

Cholesterol or serum is required for growth.

The temperature range for growth is 10 to $32^{\circ} \mathrm{C}$. Optimum growth occurs at $30^{\circ} \mathrm{C}$, and the doubling time at $30^{\circ} \mathrm{C}$ is $6.4 \mathrm{~h}$.

Serologically distinct from other established Spiroplasma species and putative groups. Isolated from the gut of a deerfly (Chrysops sp.). Pathogenicity for insects has not been determined.

The guanine-plus-cytosine content of the DNA is $30 \pm 1$ mol\%, as determined by the buoyant density method. The genome size is $1,270 \mathrm{kbp}$.

The type strain is DF-1 (= ATCC 43209).

Description of Spiroplasma gladiatoris sp. nov. Spiroplasma gladiatoris (gla.di.a'to.ris. M. L. gen. n. gladiatoris, reflecting the initial isolation of the organism from the horsefly $T$. gladiator).

Cells are filamentous, helical, and motile and lack a cell wall.

Colonies on solid medium containing 3\% Noble agar are granular with dense centers and diffuse edges, do not have satellites, and never have a fried-egg appearance.

Chemoorganotroph. Acid is produced from glucose. Does not hydrolyze arginine or urea.

Cholesterol or serum is not required for growth.

The temperature range for growth is 15 to $37^{\circ} \mathrm{C}$. Optimum growth occurs at 30 to $32^{\circ} \mathrm{C}$, and the doubling time at 30 to $32^{\circ} \mathrm{C}$ is $4.1 \mathrm{~h}$.

Serologically distinct from other established Spiroplasma species and putative groups. Isolated from the gut of a horsefly (T. gladiator). Pathogenicity for insects has not been determined.

The guanine-plus-cytosine content of the DNA is $26 \pm 1$ mol\%, as determined by the buoyant density method. The genome size has not been determined.

The type strain is TG-1 (= ATCC 43525).

Description of Spiroplasma tabanidicola sp. nov. Spiroplasma tabanidicola (ta.ba.ni.di'co.la. M. L. n. Tabanidae, family name for horseflies; L. v. colo, to inhabit; M. L. n. tabanidicola, an inhabitant of horseflies).

Cells are filamentous, helical, and motile and lack a cell wall.

Colonies on solid medium containing 3\% Noble agar are uneven and granular with dense centers and irregular edges, do not have satellites, and never have a fried-egg appearance.

Chemoorganotroph. Acid is produced from glucose. Does not hydrolyze arginine or urea.

Cholesterol or serum is required for growth.

The temperature range for growth is 10 to $37^{\circ} \mathrm{C}$. Optimum growth occurs at $30^{\circ} \mathrm{C}$, and the doubling time at $30^{\circ} \mathrm{C}$ is $3.0 \mathrm{~h}$.

Serologically distinct from other established Spiroplasma species and putative groups. Isolated from the gut of a horsefly belonging to the Tabanus abdominalis-limbatinevris complex. Pathogenicity for insects has not been determined.

The guanine-plus-cytosine content of the DNA is $26 \pm 1$ mol\%, as determined by the buoyant density method. The genome size is $1,375 \mathrm{kbp}$.

The type strain is TAUS-1 (= ATCC 51747).

Description of Spiroplasma helicoides sp. nov. Spiroplasma helicoides (he.li.coid'es. Gr. n. helix, spiral, Gr. suff. -oides, like; G L. adj. helicoides, spiral-like).

Cells are filamentous, helical, and motile and lack a cell wall.

Colonies on solid medium containing $2.25 \%$ Noble agar have dense centers and smooth edges, do not have satellites, and have a perfect fried-egg appearance.

Chemoorganotroph. Acid is produced from glucose. Does not hydrolyze arginine or urea.

Cholesterol or serum is required for growth.

The temperature range for growth is 20 to $37^{\circ} \mathrm{C}$. Optimum growth occurs at $32^{\circ} \mathrm{C}$, and the doubling time at $32^{\circ} \mathrm{C}$ is $3.0 \mathrm{~h}$.

Serologically distinct from other established Spiroplasma species and putative groups. Isolated from the gut of a horsefly (T. abactor). Pathogenicity for insects has not been determined.

The guanine-plus-cytosine content of the DNA is $26 \pm 1$ mol\%, as determined by the buoyant density method. The genome size has not been determined.

The type strain is TABS-2 (= ATCC 51746).

\section{ACKNOWLEDGMENTS}

We thank Jeffrey L. Buller, Georgia Southern University, Statesboro, for his advice concerning the specific epithets. We also thank Edward A. Clark, Francisco R. Green, J. Elaine Lowry, and Annette 
G. Wagner for assistance with isolation and culture and Mary Fenton for assistance with electron micrography.

\section{REFERENCES}

1. Abalain-Colloc, M. L., D. L. Williamson, P. Carle, J. H. Abalain, F. Bonnet J. G. Tully, M. Konai, R. F. Whitcomb, J. M. Bové, and C. Chastel. 1993 Division of group XVI spiroplasmas into subgroups. Int. J. Syst. Bacteriol 43:342-346.

2. Bové, J. M., C. Mouches, P. Carle-Junca, J. R. Degorce-Dumas, J. G. Tully, and R. F. Whitcomb. 1981. Spiroplasmas of group I. The Spiroplasma citri cluster. Yale J. Biol. Med. 56:573-582.

3. Carle, P., F. Laigret, J. G. Tully, and J. M. Bové. 1995. Heterogeneity of genome sizes within the genus Spiroplasma. Int. J. Syst. Bacteriol. 45:178181.

4. Carle, P., C. Saillard, and J. M. Bové. 1983. Determination of guanine plus cytosine content of DNA. Methods Mycoplasmol. 1:301-308.

5. French, F. E., and R. F. Whitcomb. Unpublished data.

6. French, F. E., R. F. Whitcomb, J. G. Tully, K. J. Hackett, E. A. Clark, R. B. Henegar, and D. L. Rose. 1990. Tabanid spiroplasmas of the southeast USA: new groups and correlation with host life history strategy. Zentralbl. Bakteriol. Suppl. 20:919-921.

7. Gasparich, G. E., C. Saillard, E. A. Clark, M. Konai, F. E. French, J. G. Tully, K. J. Hackett, and R. F. Whitcomb. 1993. Serologic and genomic relatedness of group VIII and group XVII and subdivision of spiroplasma group VIII into subgroups. Int. J. Syst. Bacteriol. 43:338--341.

8. International Committee on Systematic Bacteriology Subcommittee on the Taxonomy of Mollicutes. 1984. Minutes of interim meetings, 2 and 5 September 1980, Custer, South Dakota. Int. J. Syst. Bacteriol. 34:358-360.

9. International Committee on Systematic Bacteriology Subcommittee on the Taxonomy of Mollicutes. 1995. Revised minimum standards for descriptions of new species of the class Mollicutes (division Tenericutes). Int. J. Syst. Bacteriol. 45:605-612.

10. Johnson, J. L. 1994. Similarity analysis of DNAs, p. 656-682. In P. Gerhardt, R. G. E. Murray, W. A. Wood, and N. R. Krieg (ed.), Methods for general and molecular bacteriology. American Society for Microbiology, Washington, D.C.

11. Junca, P., C. Saillard, J. Tully, O. Garcia-Jurado, J. R. Degorce-Dumas, C. Mouches, J. C. Vignault, R. Vogel, R. McCoy, R. Whitcomb, D. Williamson, J. Latrille, and J. M. Bové. 1980. Caractérisation de spiroplasmes isolés d'insectes et de fleurs de France continentale, de Corse, et du Maroc: proposition pour une classification des spiroplasmes. C. R. Acad. Sci. Ser. D 290:1209-1212.

12. Konai, M., E. A. Clark, M. Camp, A. L. Koch, and R. F. Whitcomb. 1996 Temperature ranges, growth optima, and growth rates of Spiroplasma (Spiroplasmataceae, class Mollicutes) species. Curr. Microbiol. 32:1-7.

13. Konai, M., R. F. Whitcomb, J. G. Tully, D. L. Rose, P. Carle, J. M. Bové, R. B. Henegar, K. J. Hackett, T. B. Clark, and D. L. Williamson. 1995. Spiroplasma velocicrescens $\mathrm{sp}$. nov. from the vespid wasp Monobia quadridens. Int. J. Syst. Bacteriol. 45:203-206.

14. Markham, P. G., T. B. Clark, and R. F. Whitcomb. 1983. Culture techniques for spiroplasmas from arthropods. Methods Mycoplasmol, 2:217-223.

15. Rodwell, A., and R. F. Whitcomb. 1983. Methods for direct and indirect measurement of mycoplasma growth. Methods Mycoplasmol. 1:185-196.

16. Rose, D. L., J. G. Tully, J. M. Bové, and R. F. Whitcomb. 1993. A test for measuring growth responses of mollicutes to serum and polyoxyethylene sorbitan. Int. J. Syst. Bacteriol. 43:527-532.

17. Tully, J. G., J. M. Bové, F. Laigret, and R. F. Whitcomb. 1993. Revised taxonomy of the class Mollicutes: proposed elevation of a monophyletic cluster of arthropod-associated mollicutes to ordinal rank (Entomoplasma- tales ord. nov.), with provision for familial rank to separate species with nonhelical morphology (Entomoplasmataceae fam. nov.) from helical species (Spiroplasmataceae), and emended descriptions of the order Mycoplasmatales, family Mycoplasmataceae. Int. J. Syst. Bacteriol. 43:378-385.

18. Tully, J. G., and S. Razin (ed.). 1995. Molecular and diagnostic procedures in mycoplasmology, vol. 2, p. 460-462. Academic Press, San Diego, Calif.

19. Tully, J. G., D. L. Rose, E. Clark, P. Carle, J. M. Bové, R. B. Henegar, R. F. Whitcomb, D. E. Colflesh, and D. L. Williamson. 1987. Revised group classification of the genus Spiroplasma (class Mollicutes), with proposed new groups XII to XXIII. Int. J. Syst. Bacteriol. 37:357-364.

20. Tully, J. G., and R. F. Whitcomb. 1991. The genus Spiroplasma, p. 19601980. In A. Balows, H. G. Trüper, M. Dworkin, W. Harder, and K.-H. Schleifer (ed.), The prokaryotes, 2nd ed., vol. II. Springer-Verlag, New York, N.Y.

21. Wedincamp, J., Jr. 1994. Laboratory infection and release of Spiroplasma (Entomoplasmatales: Spiroplasmataceae) from horse flies (Tabanidae: Diptera). M. S. thesis. Georgia Southern University, Statesboro.

22. Wedincamp, J., Jr., F. E. French, R. F. Whitcomb, and R. B. Henegar. 1996. Spiroplasmas and entomoplasmas (Procaryotae: Mollicutes) associated with tabanids (Diptera:Tabanidae) and fireflies (Coleoptera: Lampyridae). J. Invertebr. Pathol. 68:183-186.

23. Whitcomb, R. F. 1983. Culture media for spiroplasmas. Methods Mycoplasmol. 1:147-158.

24. Whitcomb, R. F., J. M. Bové, T. A. Chen, J. G. Tully, and D. L. Williamson. 1987. Proposed criteria for an interim serogroup classification for members of the genus Spiroplasma (class Mollicutes). Int. J. Syst. Bacteriol. 37:82-84.

25. Whitcomb, R. F., F. E. French, J. G. Tully, P. Carle, R. B. Henegar, K. J. Hackett, J. R. Adams, and D. L. Williamson. Submitted for publication.

26. Whitcomb, R. F., F. E. French, J. G. Tully, G. E. Gasparich, J. M. Bové, P. Carle, E. A. Clark, and R. B. Henegar. 1992. Tabanid spiroplasma serovars. IOM Lett. 2:115.

27. Whitcomb, R. F., G. Gasparich, F. E. French, J. G. Tully, D. L. Rose, P. Carle, J. M. Bové, R. B. Henegar, M. Konai, K. J. Hackett, J. Adams, T. B. Clark, and D. L. Williamson. 1996. Spiroplasma syrphidicola sp. nov., from a syrphid (Diptera: Syrphidae) fly. Int. J. Syst. Bacteriol. 46:797-801.

28. Whitcomb, R. F., K. J. Hackett, J. G. Tully, E. A. Clark, F. E. French, R. B. Henegar, and D. L. Rose. 1990. Tabanid spiroplasmas of the southeastern USA: new groups, and correlation with host life history strategy. Zentralbl. Bakteriol. Suppl. 20:441-444.

29. Whitcomb, R. F., J. G. Tully, D. L. Williamson, J. M. Bové, F. E. French, M. Konai, G. Gasparich, M. Abalain-Colloc, C. Saillard, C. Chastel, P. Carle, D. L. Rose, R. Henegar, E. A. Clark, and K. J. Hackett. 1992. Revised classification of spiroplasmas. IOM Lett. 2:134.

30. Williamson, D. L., J. G. Tully, L. Rosen, D. L. Rose, R. F. Whitcomb, M.-L. Abalain-Colloc, P. Carle, J. M. Bové, and J. Smyth. 1996. Spiroplasma diminutum sp. nov., from Culex annulus mosquitoes collected in Taiwan. Int. J. Syst. Bacteriol. 46:229-233.

31. Williamson, D. L., J. G. Tully, and R. F. Whitcomb. 1979. Serological relationships of spiroplasmas as shown by combined deformation and metabolism inhibition tests. Int. J. Syst. Bacteriol. 29:345-351.

32. Williamson, D. L., J. G. Tully, and R. F. Whitcomb. 1989. The genus Spiroplasma, p. 71-111. In R. F. Whitcomb and J. G. Tully (ed.), The mycoplasmas, vol. 5. Academic Press, New York, N.Y.

33. Williamson, D. L., R. F. Whitcomb, and J. G. Tully. 1979. The spiroplasma deformation test, a new serological method. Curr. Microbiol. 1:203-207.

34. Williamson, D. L., R. F. Whitcomb, J. G. Tully, G. E. Gasparich, D. L. Rose, P. Carle, J. M. Bové, K. J. Hackett, R. B. Henegar, M. Konai, and F. E. French. 1996. Revised group classification of the genus Spiroplasma. IOM Lett. 4:217. 